\title{
A batalha da mídia: da formação dos oligopólios à luta pela democratização da comunicação
}

\author{
MORAES, D.; RAMONET, I.; \\ SERRANO, P. (orgs). \\ Mídia, poder e contrapoder: \\ da concentração monopólica à \\ democratização da informação. \\ São Paulo: Boitempo, 184 p., 2013.
}

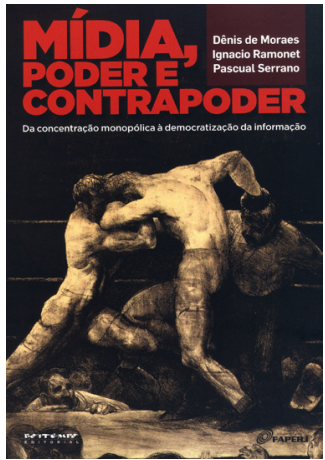

Resumo: Em Mídia, poder e contrapoder, Moraes, Ramonet e Serrano discutem o elevado índice de concentração oligopólica, atualmente observado na área da comunicação, setor este que, em nível mundial, encontra-se dominado por cerca de sete megagrupos. Ademais, os pensadores questionam as consequências danosas que as políticas neoliberais (juntamente com a "invasão" do "grande capital" no setor midiático) podem acarretar à democracia, como manipulação e censura da informação.

Palavras-chave: mídia; democratização; jornalismo alternativo.

Abstract: In Mídia, poder e contrapoder, Moraes, Ramonet and Serrano discuss the high rate of oligopolistic concentration currently observed in the field of communication, a sector that globally is dominated by about seven corporations. In addition, the authors question 
the harmful consequences that neoliberal politics (together with the "invasion" of the "great capital" in the media sector) may have on democracy, such as manipulation and censorship of information.

Keywords: media; democratization; alternative journalism.

Em Mídia, Poder e Contrapoder, Dênis de Moraes, Ignacio Ramonet e Pacual Serrano debatem a importância (e urgência) da elaboração e concretização de políticas e medidas que visem à democratização dos meios de comunicação no contemporâneo, posicionando-se de maneira contra-hegemônica em relação às estratégias mercantis das grandes corporações do setor.

Na primeira parte do livro, de modo geral, os autores discutem o processo de expansão dos conglomerados de comunicação - com a exceção de alguns poucos países, caso de Venezuela, Equador, Bolívia, Uruguai e Argentina, aos quais se referem como "progressistas" -, motivo pelo qual observamos um alarmante nível de concentração oligopólica na área, mundialmente dominada por sete megagrupos que contam com a ajuda e/ou suporte de uma verdadeira invasão ou enxurrada financeira (na forma de investimentos, fusões, alianças, participações, etc.) do grande capital.

Feitas as considerações primordiais, dentre as principais críticas que os autores introduzem na discussão, está a falácia que os oligopólios midiáticos ergueram em torno da ideia de "liberdade de imprensa", escusa segundo a qual os meios de comunicação teriam logrado alcançar "um nível de impunidade impressionante" (2013, p. 73). E mais: para os pesquisadores, seriam os próprios controladores da mídia atual que conduziriam algumas das maiores estratégias de censura à liberdade de informação, uma vez que seriam eles que (a) decidem o que deve ser publicado/exibido (ou não) em seus espaços, (b) podem nos bombardear com excesso de "informações inúteis" e (c) podem ainda silenciar determinadas vozes - em especial as opositoras -, estabelecendo um genuíno quadro de "desinformação".

Já na segunda parte do ensaio, Moraes, Ramonet e Serrano dedicam-se à análise de propostas reais de democratização dos media na América Latina, seja por reformas no âmbito legal, como a Ley de Medios argentina, seja pela elaboração de um jornalismo crítico e combativo ao atual sistema de comunicação pró-status quo, como as "agências de notícias alternativas", analisadas às dezenas no livro, as quais envolvem ações e projetos contra-hegemônicos, que atuam principalmente por meio da internet, exatamente por demandar uma tecnologia relativamente barata e oferecer acesso e uso facilitados.

Consoante os pesquisadores, são principalmente as ferramentas disponibilizadas pela web 2.0, tais quais as redes sociais e os blogs, que contribuem para a elaboração desse "jornalismo novo", facilitando o acesso à informação não oriunda dos conglomerados de mídia. Alguns dos efeitos diretos dessa nova realidade, para o trio, seriam a intensificação da crise dos meios de comunicação mercantis, uma tensão que atravessaria justamente alguns dos pontos-chave do jornalismo, como as noções de credibilidade, objetividade e autoridade. 
Por fim, os autores defendem o argumento de que as mídias alternativas têm que investir tanto nas plataformas e possibilidades disponibilizadas pela internet quanto na interação com os internautas, facilitando desde a produção e difusão de informações pelos indivíduos até à possibilidade de que as notícias sejam comentadas e compartilhadas pelos leitores, ademais da necessidade de internacionalizá-las, objetivando serem igualmente compreendidas no além das fronteiras nacionais, necessitando, para isso, basicamente, de adaptações ou ajustes no vocabulário empregado. Tais medidas não só colaboram na difusão da informação alternativa, como acrescentam mais espaço para o ecoar das vozes muitas vezes emudecidas pelos grupos midiáticos hegemônicos, contribuindo, ainda, para o declínio ou ruptura do "monopólio da informação".

Bruno Thebaldi é doutorando em Comunicação na PUC-Rio e mestre em comunicação pela UFF. 